\title{
Metagenomic analyses of the late Pleistocene permafrost - additional tools for reconstruction of environmental conditions
}

\author{
Elizaveta Rivkina $^{1}$, Lada Petrovskaya $^{2}$, Tatiana Vishnivetskaya ${ }^{1,3}$, Kirill Krivushin $^{1}$, Lyubov Shmakova ${ }^{1}$, \\ Maria Tutukina ${ }^{4,7}$, Arthur Meyers ${ }^{3}$, and Fyodor Kondrashov ${ }^{4,5,6}$ \\ ${ }^{1}$ Institute of Physicochemical and Biological Problems in Soil Science, Russian Academy of Sciences, Pushchino, Russia \\ ${ }^{2}$ Shemyakin and Ovchinnikov Institute of Bioorganic Chemistry, Russian Academy of Sciences, Moscow, Russia \\ ${ }^{3}$ University of Tennessee, Center for Environmental Biotechnology, Knoxville, USA \\ ${ }^{4}$ Bioinformatics and Genomics Programme, Centre for Genomic Regulation (CRG), Barcelona, Spain \\ ${ }^{5}$ Universitat Pompeu Fabra (UPF), Barcelona, Spain \\ ${ }^{6}$ Institució Catalana de Recerca i Estudis Avançats (ICREA), Barcelona, Spain \\ ${ }^{7}$ Institute of Cell Biophysics, Russian Academy of Sciences, Pushchino, Russia
}

Correspondence to: Elizaveta Rivkina (elizaveta.rivkina@gmail.com)

Received: 17 June 2015 - Published in Biogeosciences Discuss.: 4 August 2015

Revised: 25 March 2016 - Accepted: 6 April 2016 - Published: 15 April 2016

\begin{abstract}
A comparative analysis of the metagenomes from two 30 000-year-old permafrost samples, one of lake-alluvial origin and the other from late Pleistocene Ice Complex sediments, revealed significant differences within microbial communities. The late Pleistocene Ice Complex sediments (which have been characterized by the absence of methane with lower values of redox potential and $\mathrm{Fe}^{2+}$ content) showed a low abundance of methanogenic archaea and enzymes from both the carbon and nitrogen cycles, but a higher abundance of enzymes associated with the sulfur cycle. The metagenomic and geochemical analyses described in the paper provide evidence that the formation of the sampled late Pleistocene Ice Complex sediments likely took place under much more aerobic conditions than lake-alluvial sediments.
\end{abstract}

\section{Introduction}

Permafrost, including constantly frozen sediments of the Arctic, is a unique subsurface complex environment where microorganisms retain viability over a long period of time, from thousands to millions of years (Gilichinsky and Rivkina, 2011). The impact of climate change on permafrost stability has recently been discussed widely by the scientific community (Zimov et al., 2006; Walter et al., 2007; Anthony Walter et al., 2014). The permafrost deposits of northeast- ern Siberia, which did not thaw during the Holocene climatic optimum, have attracted particular interest, especially the late Pleistocene Ice Complex deposits (Yedoma Suite) that are widespread on the eastern Siberian coastal plains (LenaAnabar, Yana-Indigirka, and Kolyma lowlands) (Schirrmeister et al., 2011). It was found earlier that the epigenetically (consecutively) frozen sediments of both lake and marine origin (independent of age) contain biogenic methane in concentration up to $1.3 \mathrm{mmol} \mathrm{kg}^{-1}\left(\sim 30 \mathrm{~mL} \mathrm{~kg}^{-1}\right)$, whereas methane was either absent or present at trace concentrations $\left(<0.0002 \mu \mathrm{mol} \mathrm{kg}{ }^{-1}\right)$ in samples from the sincryogenic (simultaneously frozen) late Pleistocene Ice Complex located in the Yana-Indigirka and Kolyma lowlands (Rivkina et al., 2007; Rivkina and Kraev, 2008). However, Yedoma deposits found on the Tyungylyn Terrace of the Lena River (central Yakutia) in a zone of boreal forest contained methane in concentrations up to $6000 \mathrm{ppmv}$ in pore space of permafrost (Brouchkov and Fukuda, 2002). Studies conducted on Kurungnakh Island, which is situated in the southern part of the Lena River delta, showed the presence of biogenic methane in Holocene sediments (up to $3.5 \mathrm{mmol} \mathrm{kg}^{-1}$ ), while methane concentrations in the majority of samples from late Pleistocene Ice Complex were at a detection level and only some samples from Ice Complex sediments approximately 28000 years old showed the presence of methane in a concentration of $1.0 \mathrm{mmol} \mathrm{kg}^{-1}$ 
and methane concentration increased up to $2.0 \mathrm{mmol} \mathrm{kg}^{-1}$ in sediments either younger than 16000 years or older than 40000 years (Bischoff et al., 2013). The presence of biogenic methane up to $0.4 \mathrm{mmol} \mathrm{kg}^{-1}$ in the Ice Complex deposits on the Gydan Peninsula located on the Siberian coast of the Kara Sea between the estuaries of the $\mathrm{Ob}$ and Yenisei rivers was also shown during our recent research (unpublished data). These data indicate that different types of Yedoma deposits are present in different parts of the Siberian Arctic. Schirrmeister et al. (2013) pointed out that "the typical Ice Complex formation consisted of several concurrent cryogenic processes, including sediment accumulation and freezing, ice segregation, syngenetic ice-wedge growth, sediment reworking, peat aggradation, cryosol formation, and cryoturbation". Different ways of Yedoma formation are presumably reflected in the possibility of the methane formation and its preservation in Yedoma sediments. Studies reviewed above showed an absence of methane in the late Pleistocene Ice Complex on the territory of the Yana-Indigirka and Kolyma lowlands.

Anaerobic microcosm incubation of thawed permafrost samples in a carbon dioxide - and hydrogen - enriched atmosphere showed methanogenic activity in epicryogenic sediments only, while this process was not observed in samples from the sincryogenic late Pleistocene Ice Complex (Rivkina and Kraev, 2008). Similar results were obtained during experiments with radioactively labeled substrates (Rivkina et al., 2006, 2004, 2007), showing an absence of methanogenic activity in the sincryogenic late Pleistocene Ice Complex samples with this process evidently taking place in epicryogenic sediments of lake or lakealluvial origin. Moreover, only from the latter sediments $\left(1.3 \mathrm{mmol} \mathrm{CH}_{4} \mathrm{~kg}^{-1}\right)$ methanogenic archaea were isolated in pure culture (Rivkina et al., 2007; Krivushin et al., 2010; Shcherbakova et al., 2011). Viable methanogens were also isolated from the permafrost-affected soils located in the Lena River delta region (Morozova et al., 2007; Wagner et al., 2013; Liebner et al., 2007).

The specific distribution of methane and methanogenic activity in permafrost raises a number of questions relating to the composition of microbial communities and particulary to abundance and composition of methane-producing microorganisms. Certainly, the application of new methodologies such as metagenomic analyses is required to estimate diversity and complexity of permafrost microbial communities, as well as gaining insight into their metabolic capabilities (Graham et al., 2012; Jansson and Tas, 2014). Until recently, the determination of microbial diversity in low-biomass environments, including permafrost, was problematic. The microbial cell abundances in the ancient permafrost is 10-100 times lower than that in the active layer samples, thereby resulting in low yields of the total community genomic DNA (gDNA) (Yergeau et al., 2010). However, using appropriate DNA extraction kits (Vishnivetskaya et al., 2014) and the whole-community genome amplification technique (Yergeau et al., 2010), a sufficient amount of gDNA can be obtained for next-generation sequencing technologies, producing sequences on an unprecedented scale. Indeed, the first metagenomic analyses of permafrost samples became available recently (Mackelprang et al., 2011; Jansson and Tas, 2014). Specifically, the analyses of the metagenomes from active layer soil and $2 \mathrm{~m}$ deep permafrost samples collected in the Canadian High Arctic and Alaska identified signature genes responsible for hydrogenotrophic and acetoclastic methanogenesis, methylotrophic methane oxidation, nitrification, and carbohydrate degradation (Yergeau et al., 2010; Mackelprang et al., 2011).

Here we report results of the comparative metagenomic analyses of the two ancient permafrost samples similar in age (ca. 30000 years old) but of different origins (epigenetically frozen lake sediments vs. sincryogenic sediments from the late Pleistocene Ice Complex). The aim of the study was to analyze the abundance and composition of microbial communities from the late Pleistocene permafrost of different origin and elucidate why the sediments of the late Pleistocene Ice Complex in the Kolyma-Indigirka lowland do not contain methane or methanogenic activity. The second objective of the study was to compare putative metabolic capabilities of the communities and use these findings for explanation of a possible scenario of the development of low methane Yedoma sediments.

\section{Materials and methods}

\subsection{Sample collection and description}

Samples were collected within the Kolyma-Indigirka lowland in northeastern Siberia $\left(152-162^{\circ} \mathrm{E}, 68-72^{\circ} \mathrm{N}\right)$ during the summer field season of 2007 (Fig. 1a). Permafrost sediments were sampled using drilling equipment that operates without fluids and prevents down-hole contamination. The sampling technique was tested and described previously (Shi et al., 1997). Briefly, the surfaces of the 20 to $30 \mathrm{~cm}$ long cores were cleaned immediately by shaving melted layers out with an ethyl alcohol-sterilized knife and then the frozen internal part of the core was split into $5 \mathrm{~cm}$ long segments; these were placed into sterile aluminum containers and kept frozen during storage in field and transportation to the Institute of Physicochemical and Biological Problems in Soil Science, Pushchino. The physicochemical characteristics of the samples are presented in Table 1. Gas samples were collected by degassing $50 \mathrm{~g}$ of frozen cores in a $150 \mathrm{~mL}$ syringe under nitrogen atmosphere as described previously (Rivkina et al., 2007; Rivkina and Kraev, 2008). $\mathrm{CH}_{4}$ concentration was measured by headspace equilibration using a KhPM-4 gas chromatograph (Moscow Chromatograph, Russia) with flame ionization detector and hydrogen as a carrier gas. The $\delta^{13} \mathrm{C}$ of methane was analyzed on a Thermo Finnigan GC 


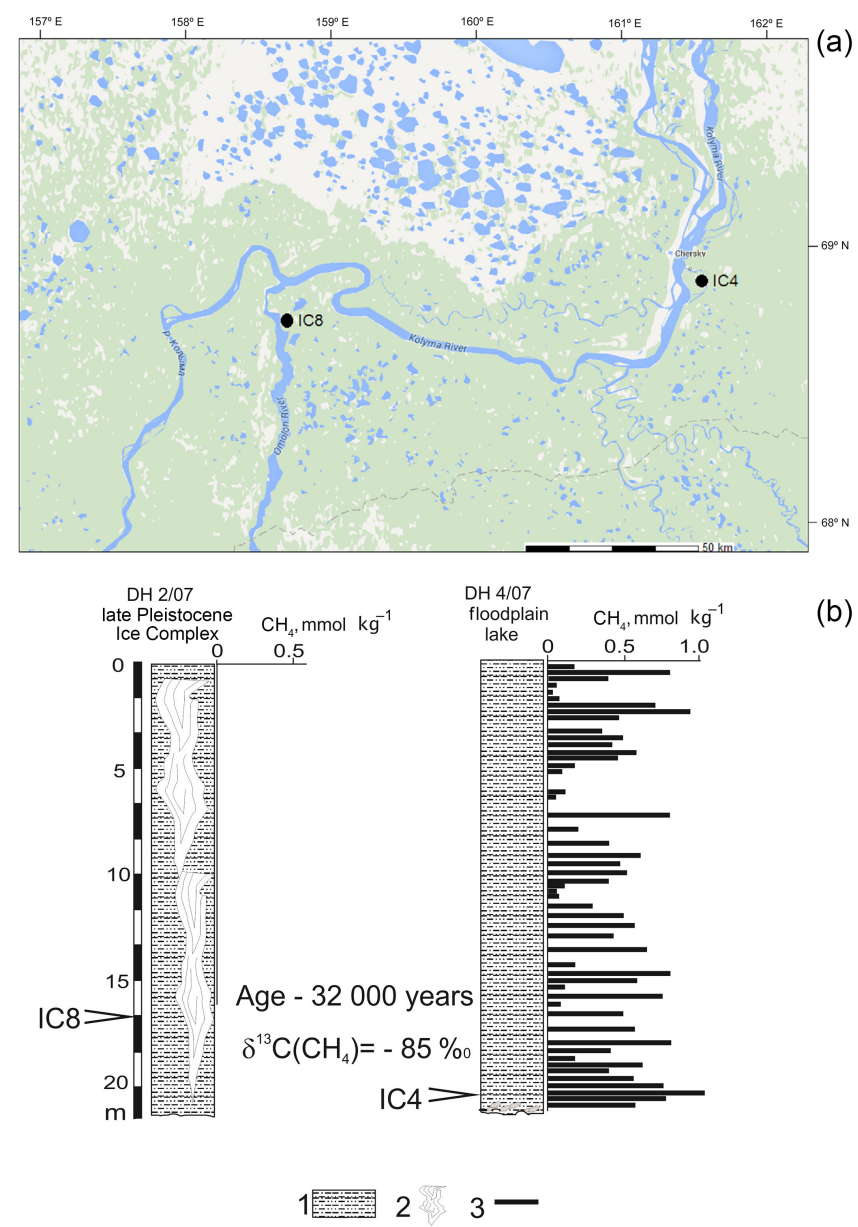

Figure 1. Location of sampling sites on the Kolyma lowland (a). The position of samples IC4 and IC8 in drilling holes and methane content from different depth of these boreholes (b): 1 - sandy loam; 2 - sand with gravel; 3 - ice wedges; 4 - methane content.

Combustion III interface and Deltaplus XL mass spectrometer (Thermo Electron Corporation, Germany).

Sample IC4 corresponded to the permafrost sediment of lake origin from the floodplain of the Ambolikha River, borehole DH-4/07, depth $22.5 \mathrm{~m}$ (Fig. 1b). Total carbon concentration was $\sim 1.1 \%(w / w)$. Methane content of this sample was $1.2 \mathrm{mmol} \mathrm{kg}^{-1}, \delta^{13} \mathrm{C}=-85 \%$, indicative of biogenic origin. The radiocarbon age of this sample was $30696 \pm 394$ years (J-5829) (Kraev et al., 2013).

Sample IC8 represented a permafrost soil from the late Pleistocene Ice Complex (Omolon River), borehole DH$2 / 07$, depth $16 \mathrm{~m}$. Total carbon concentration was $\sim 1.1 \%$ $(w / w)$. Methane levels in all samples tested from this borehole were $<0.0002 \mathrm{mmol} \mathrm{kg}^{-1}$ (Fig. 1b). The age of this sample was estimated to be $\sim 32000$ years, based on the age determination for the same outcrop which was described recently (Legendre et al., 2014).

\subsection{DNA extraction and sequencing}

In the laboratory, material from the inner part of the permafrost cores was subsampled aseptically for DNA isolation. The gDNA was extracted from eight replicates of $\sim 0.5 \mathrm{~g}$ each randomly taken from $\sim 50 \mathrm{~g}$ of permafrost core collected at corresponding depth (Fig. 1) using the PowerSoil ${ }^{\circledR}$ DNA Extraction Kit (MO BIO Laboratories Inc., USA). Due to low yield (3-6ng $\mu \mathrm{L}^{-1}$ ), gDNAs from eight replicates were combined, then purified and concentrated using $\mathrm{Ge}$ nomic DNA Clean and Concentrator ${ }^{\circledR}$ Kit (Zymo Research Corporation, USA).

The gDNA sequencing libraries were prepared using NEBNext ${ }^{\circledR}$ reagents (New England BioLabs Inc., USA), according to protocol recommended by the manufacturer, having an estimated peak insert size of $150 \mathrm{nt}$. Metagenome sequencing was performed at the CRG Genomics Core Facility (Centre for Genomic Regulation, Barcelona, Spain) on an Illumina HiSeq $2000^{\mathrm{TM}}$ machine using Flow Cell v3 with TruSeq SBS v3 reagents and a $2 \times 100$ cycle sequencing protocol.

\subsection{MG-RAST analysis}

Raw sequencing data (i.e., $19.8 \mathrm{~Gb}$, representing $143.7 \mathrm{M}$ sequences with an average length of $138 \mathrm{bp}$ for IC4, and $19.7 \mathrm{~Gb}$, representing $131.7 \mathrm{M}$ sequences with an average length of $150 \mathrm{bp}$ for IC8) were uploaded to the MG-RAST server (Meyer et al., 2008) for gene calling and annotation under ID 4606864.3 for IC4 and 4606865.3 for IC 8 . A total of $6.6 \%$ (IC4) and $3.4 \%$ (IC8) of the sequences failed to pass the quality control (QC) pipeline, whereas $0.3 \%$ of the total sequences in both data sets were assigned to ribosomal RNA genes.

For functional assignment, protein sequences of putative ORF were searched against the M5NR non-redundant protein database (Wilke et al., 2012) with an e-value threshold of $1 \mathrm{e}^{-5}$, minimum percentage identity of $60 \%$, and minimum alignment length of $15 \mathrm{aa}$. The taxonomic assignments of Illumina reads were performed against M5NR and M5RNA databases at default parameters. The best-hit classification method was used in both cases for match assessment.

\subsection{Comparative metagenomic data analyses}

Statistical analyses of the metagenomes were performed in order to compare community composition and functional profiles of the permafrost samples. Statistical significance was calculated using the two-sided Fisher's exact test. The differences between proportions were analyzed in STAMP (Parks and Beiko, 2010) using the MG-RAST taxonomic profile and the Newcombe-Wilson method (Newcombe, 1998) at a $95 \%$ confidence interval and with Storey's false discovery rate (FDR) correction (Storey and Tibshirani, 2003; Storey et al., 2004). Original data sets were deposited 
Table 1. Physicochemical characteristics of two permafrost soils.

\begin{tabular}{|c|c|c|c|c|c|c|c|c|c|c|c|c|c|c|c|}
\hline \multirow[t]{3}{*}{ Samples } & \multicolumn{3}{|c|}{ Grain-size distribution } & \multirow{2}{*}{$\begin{array}{r}\text { Ice } \\
\text { content }\end{array}$} & \multirow[t]{2}{*}{ Eh } & \multirow[t]{2}{*}{$\mathrm{C}_{\mathrm{tot}}$} & \multicolumn{9}{|c|}{ Water extract $(1: 5)$} \\
\hline & Sand & Silt & Clay & & & & Dry residue & $\mathrm{pH}$ & $\mathrm{HCO}_{3}^{-}$ & $\mathrm{Cl}^{-}$ & $\mathrm{SO}_{4}^{2-}$ & $\mathrm{Ca}^{2+}$ & $\mathrm{Mg}^{2+}$ & $\mathrm{K}^{+}$ & $\mathrm{Na}^{+}$ \\
\hline & & $\%$ & & $\%$ & $\mathrm{mV}$ & $\%$ & $\%$ & \multicolumn{8}{|c|}{ Meq/100 g dry soil } \\
\hline IC4 & 79.44 & 15.84 & 4.72 & 17.5 & 45 & 1.1 & 0.130 & 7.22 & 0.12 & 1.40 & 0.14 & 0.32 & 0.42 & 0.06 & 1.33 \\
\hline IC 8 & 40.72 & 52.72 & 6.56 & 27.6 & 167 & 1.2 & 0.135 & 8.16 & 0.57 & 0.32 & 0.48 & 0.75 & 0.35 & 0.02 & 0.56 \\
\hline
\end{tabular}

at the NCBI Sequence Read Archive (SRA) under the accession numbers SRX763249 and SRX751044 (Krivushin et al., 2015).

\section{Results and discussion}

\subsection{Community description}

The gDNA yield was higher in IC8 sample, with an average of $0.5 \mu \mathrm{g} \mathrm{g}^{-1}$ of wet sediment, in comparison to $0.37 \mu \mathrm{g} \mathrm{g}^{-1}$ in the IC4 sample. For gDNA isolation, the PowerSoil ${ }^{\circledR}$ DNA Extraction Kit (MO BIO Laboratories Inc., USA) was selected based on its performance and cost per sample. Previously it has been shown that the gDNA extraction efficiency (based on the measurement of mCherry plasmid copies) for this kit was $98 \%$, whereas efficiency of gDNA extraction from permafrost was estimated at $16 \pm 8 \%$ (Vishnivetskaya et al., 2014). The theoretical levels of the prokaryotic cell populations for studied samples were calculated from the total gDNA recovered, an average genome length of $4.7 \mathrm{Mb}$ for the soil bacterial/archaeal population estimated from the metagenomics data (Angly et al., 2009; Raes et al., 2007), and a weight of $4.05 \mathrm{fg}$ (Ellenbroek and Cappenberg, 1991) for a genome of this size. Accounting for an average extraction efficiency and including a reduction of the total cell population by the eukaryotic component equal to $25 \%$ (Raes et al., 2007), the estimated prokaryotic cell populations were $4.3 \times 10^{8}$ cells g $^{-1}$ for IC4 and $5.9 \times 10^{8}$ cells g $^{-1}$ for IC8.

For gDNA extractions from permafrost, the PowerSoil ${ }^{\circledR}$ DNA Extraction Kit (MO BIO Laboratories Inc., USA) was shown to be reliable, providing similar microbial community structure results with minimal variations among triplicates $(P>0.05)$ (Vishnivetskaya et al., 2014). Analyses of metagenomes of the two permafrost samples showed that bacterial genes were dominant and 96.4 and $97.7 \%$ of sequences were assigned to the domain Bacteria in the IC4 and IC8 samples, respectively. Archaea were the second dominant domain followed by Eukaryotes, while viruses comprised only $0.06 \%$ in IC4 and $0.03 \%$ in IC8 samples. Archaea and Eukaryotes were more abundant in the IC4 sample compared to the IC 8 sample, i.e., $2.4 \%$ vs. $1.3 \%$ and $1.0 \%$ vs. $0.9 \%$, respectively. Representation of Bacteria in the metagenomic data was significantly higher than Eukary- otes. A similar pattern has been observed in metagenomic data sets obtained from other soils including cold deserts and tundra (Fierer et al., 2012). Bailly et al. (2007) showed that, in spite of the fact that eukaryotic organisms represented a large portion of the microbial biomass in soil, detection of eukaryotes in metagenomes is low because they are physically excluded (by filtration or centrifugation on density gradients) from the biomass before DNA extraction. Nevertheless, during the current study it was observed that a number of detected unparalleled genes of eukaryotic organisms, including plants, algae, fungi, and protists, were 3.4 and 2.6 times higher in comparison to a number of Bacterial unparalleled genes detected in the IC4 and IC8 samples, respectively. Eukaryotic organisms including fungi have a genome size several orders of magnitude higher than the genome size of a bacterium. Eukaryotic genome sizes vary from, for example, $13.8 \mathrm{Mb}$ for the yeast Schizosaccharomyces pombe (with 4800 protein coding genes) to $69 \mathrm{Mb}$ for the ciliate Paramecium tetraurelia (39600 gene models) (Bailly et al., 2007). Both of these free-living unicellular eukaryotes were detected in IC4, while only members of the genus Schizosaccharomyces were detected in IC8 at lower abundance. It is likely that a metagenomic library based on gDNA can capture a significant functional diversity in spite of low representation of a eukaryotic microbial community.

The most abundant microorganisms were comprised of nine bacterial and one archaeal phyla, with Proteobacteria being the most plentiful, followed by Actinobacteria, Firmicutes, Bacteroidetes, Chloroflexi, Planctomycetes, Euryarchaeota, Acidobacteria, Cyanobacteria, and Verrucomicrobia in that order (Fig. 2). The quantities of all other phyla were less than $1 \%$. Sequences affiliated with Actinobacteria $\left(P<1 \mathrm{e}^{-15}\right)$, Firmicutes $\left(P<1 \mathrm{e}^{-15}\right)$, Chloroflexi $\left(P<1 \mathrm{e}^{-15}\right)$, Cyanobacteria $\left(P<1 \mathrm{e}^{-15}\right)$, Acidobacteria $\left(P<1 \mathrm{e}^{-15}\right)$, Verrucomicrobia $\left(P<1 \mathrm{e}^{-15}\right)$ were dominant within IC8, whereas $\alpha-, \beta-, \gamma-$, and $\delta$-Proteobacteria $\left(P<1 \mathrm{e}^{-15}\right)$, Bacteroidetes $\left(P<1 \mathrm{e}^{-15}\right)$, Planctomycetes $\left(P<1 \mathrm{e}^{-15}\right)$, and Euryarchaeota $\left(P<1 \mathrm{e}^{-15}\right)$ dominated within IC4. The microorganisms that are involved in methane formation and methane metabolism, for example methanogenic archaea (phylum Euryarchaeota) or methanotrophic and methylotrophic bacteria (phylum Proteobacteria), were twice more abundant in the more reduced IC4 sample $(E h=45 \mathrm{mV})$ than in the less reduced IC8 


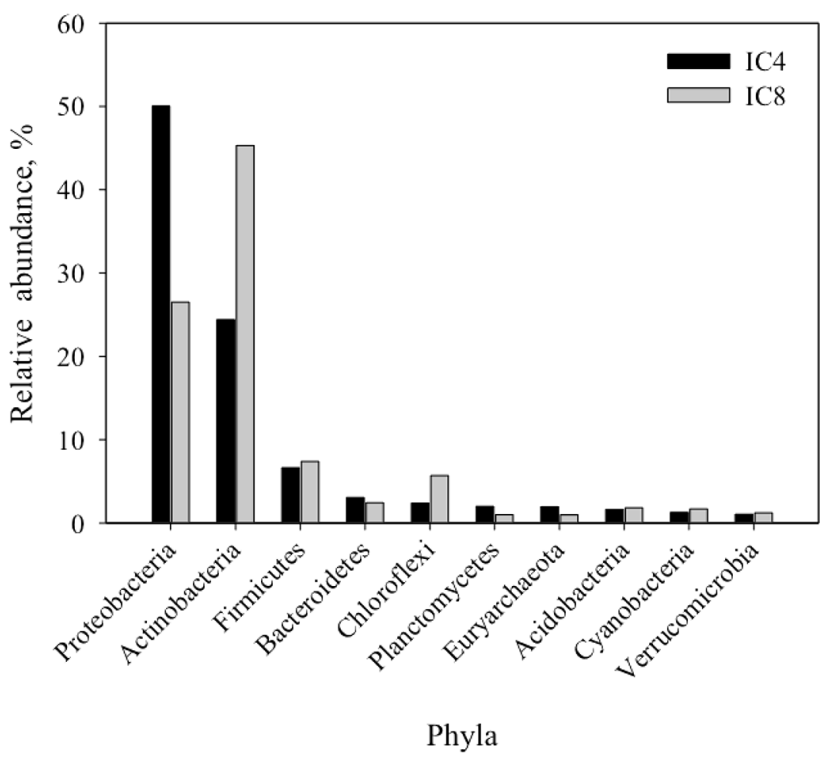

Figure 2. Community analyses of the IC4 and IC 8 metagenomes at phylum level. The phyla present in metagenomes at a $>1 \%$ level are shown.

$(E h=167 \mathrm{mV})$. Methanogenic and methanotrophic reactions operate at opposite redox conditions of -250 and $+250 \mathrm{mV}$, respectively. Estimated value of the redox potential in the permafrost samples does not support prevalence of either methanogenesis or methane oxidation. The observation that the late Pleistocene samples with higher proportion of sands contain low methane concentrations (Bischoff et al., 2013) was not supported during the current study (Table 1). Microorganisms without strong association to methane metabolism (e.g. phyla Actinobacteria and Chloroflexi) dominated in IC8.

\subsection{Dependence of the microbial community structure on permafrost characteristics as detected from genus taxonomical level}

\subsubsection{Methanogenic community}

As was shown in previous research (Kraev et al., 2013; Legendre et al., 2014), methane was not detected in the IC8 sample, but its level in the IC4 sample reached 1$2 \mathrm{mmol} \mathrm{kg}-1$; hence, one would expect to find a greater abundance of methanogenic species in the IC4 sample. Indeed, the phylum Euryarchaeota, which contains methanogens, was twice as prevalent in the IC4 sample, and methanogenic Archaea constituted as much as $1.5 \%$ of the microbial communities in IC4 (compared to $0.5 \%$ in IC8). The most abundant methane-producing species was Methanosarcina ( $0.32 \%$ in IC4 vs. $0.14 \%$ in IC8), followed by Methanoregula (0.28\% vs. $0.03 \%)$, Methanoculleus (0.1\% vs. $0.05 \%)$, Methanosphaerula (0.1\% vs. $0.03 \%)$, Methanospirillum $(0.1 \%$ vs. $0.03 \%)$, and Methanosaeta $(0.1 \%$ vs. $0.03 \%)$.
Twelve other methanogenic species were detected at $<0.1 \%$ in IC4 and at an even lower percentage in IC8.

\subsubsection{Methanotrophic bacteria}

In the vicinity of the environments where methane is produced, methane-oxidizing (methanotrophic) bacteria can be found (Khmelenina et al., 2002). Thus, we analyzed the presence of methanotrophic DNA in our data. To date, two types of methane-oxidizing bacteria are recognized, type I methanotrophs belonging to $\gamma$-Proteobacteria and type II methanotrophs from $\alpha$-Proteobacteria. Indeed, the phylum Proteobacteria clearly dominated in the IC4 sample (50.0\% vs. $26.5 \%$ in IC8) with the $\alpha$-Proteobacteria being more abundant in IC4 $(32.7 \%)$ in comparison to IC8 $(12.3 \%)$. On a more refined taxonomical scale the most abundant order of $\alpha$-Proteobacteria was Rhizobiales (24.2\% in IC4 vs. $7.7 \%$ in IC8), which contains both methanotrophic and nitrogen-fixing bacteria. The $\alpha$-Proteobacteria type II methanotrophs ( $3.32 \%$ vs. $1.06 \%)$ were represented by the genera Methylocella (0.53\% vs. $0.14 \%)$, Methylosinus $(0.24 \%$ vs. $0.07 \%)$, Methylocystis $(0.22 \%$ vs. $0.06 \%)$, and Methylobacterium (2.32\% vs. $0.8 \%)$ in IC4 and IC 8 . The last genus (Methylobacterium) is a facultative methylotroph, however, some species are capable of growth on methane. The class $\gamma$-Proteobacteria was the most diverse Proteobacteria class (184 species); nonetheless, it was sixfold less plentiful in comparison to $\alpha$-Proteobacteria. The $\gamma$ Proteobacteria type I methanotrophs, such as Methylococcus $(0.13 \%$ vs. $0.11 \%)$, Methylobacter $(0.12 \%$ vs. $0.05 \%)$, and Methylophaga (0.02\% vs. $0.01 \%)$ were again more abundant in the IC4 than in the IC8 sample. In this Siberian permafrost, type II methanotrophs dominated over type I methanotrophs, which is similar to methanotrophic bacteria abundance and diversity in Canadian High Arctic permafrost (Lau et al., 2015). Methylotrophs, as well as the subset methanotrophs, play an essential role in the carbon cycle. Interestingly, obligate methylotrophic bacteria belonging to the $\beta$-Proteobacteria, such as Methylibium ( $0.17 \%$ vs. $0.16 \%)$, Methylobacillus ( $0.07 \%$ vs. $0.08 \%)$, Methylovorus $(0.04 \%$ vs. $0.04 \%)$, and Methylotenera $(0.06 \%$ vs. $0.05 \%)$, were detected in both the IC4 and IC8 samples at equally low levels.

\subsubsection{Bacteria of nitrogen cycle}

The nitrogen cycle includes several microbial processes such as $\mathrm{N}_{2}$ fixation, ammonification, nitrification, and denitrification. Nitrogen-fixing bacteria more abundant in the IC4 were represented by the genera Bradyrhizobium (1.85\% vs. $0.5 \%)$, Sinorhizobium (1.3\% vs. 0.6\%), Rhizobium ( $0.82 \%$ vs. $0.4 \%)$, Rhodospirillum ( $0.63 \%$ vs. $0.3 \%)$, Afipia $(0.4 \%$ vs. $0.12 \%)$, and the $\gamma$-Proteobacteria nitrogen-fixing species. Other species involved in the nitrogen cycle from the Hyphomicrobium ( $2.5 \%$ vs. $0.23 \%$, capable of denitri- 
fication with methanol), Nitrobacter $(1.9 \%$ vs. $0.6 \%$, capable of oxidizing nitrite into nitrate), and Rhodopseudomonas (3.8\% vs. $1.2 \%$, capable of carbon dioxide and nitrogen fixation) genera were also more abundant in the IC4 sample. However, ammonia-oxidizing and nitrifying bacteria of the class $\beta$-Proteobacteria, such as Nitrosomonas $(\sim 0.1 \%)$ and Nitrosospira $(\sim 0.17 \%)$, were detected in both samples at a similar level. Other bacteria involved in the nitrogen cycle are members of the phylum Planctomycetes, many of which conduct anaerobic ammonium oxidation or so-called "anammox" metabolism, a process of ammonia oxidation by nitrite involvement to yield nitrogen gas. Four planctomycete genera were more abundant in IC4 compared to the IC8 sample, with Planctomyces $(0.63 \%$ vs. $0.34 \%)$ being the most abundant, followed by Pirellula (0.61\% vs. $0.28 \%)$, Blastopirellula $(0.57 \%$ vs. $0.24 \%)$, and Isosphaera $(0.16 \%$ vs. $0.13 \%$ ). Some planctomycetes, e.g., Pirellula, are able to live in environments with high inorganic sulfate concentrations (Glockner et al., 2003). Nitrogen-fixing cyanobacteria slightly dominated in IC8 $(0.82 \%)$ in comparison to IC4 $(0.71 \%)$; however, the proportion of nitrogen fixing to the total amount of cyanobacteria was higher in the IC4 $(55.5 \%)$ than in the IC8 $(48.6 \%)$ sample. Another nitrogen-fixing bacterium dominating in IC8 $(2.6 \%)$ in comparison to IC4 $(0.8 \%)$ was the actinobacterium Frankia, which is characterized by the ability to engage in a symbiotic relationship with plants, producing nitrogen-fixing root nodules.

\subsubsection{Sulfate-reducing bacteria}

The $\delta$-Proteobacteria were also more abundant in IC4 (5.8\%) than in IC8 $(4.5 \%)$. Sulfate-reducing bacteria, namely Desulfovibrio (0.49\% vs. $0.41 \%)$, Desulfatibacillum (0.22\% vs. $0.08 \%$ ), Desulfococcus (0.18\% vs. $0.07 \%)$, Desulfobacterium $(0.14 \%$ vs. $0.04 \%)$, Desulfomicrobium $(0.11 \%$ vs. $0.06 \%$ ), and metal-reducing bacteria of the genus Geobac$\operatorname{ter}(1.13 \%$ vs. $0.82 \%)$, were more plentiful in the IC4 sample. Two species from the order Syntrophobacterales were more abundant in IC4; these included the strictly anaerobic, sulfate-reducing, propionate-degrading bacterium Syntrophobacter $(0.33 \%$ vs. $0.18 \%$ in IC8) and the benzoatedegrading bacterium Syntrophus (0.62\% vs. $0.13 \%)$. During growth on certain compounds, both of these organisms are known to form syntrophic associations with methanogens, e.g., Methanospirillum hungateii, facilitating methane production (Harmsen et al., 1998; Jackson et al., 1999). The sulfate-reducing bacterium Desulfotomaculum from the phylum Firmicutes was found at a similar concentration in both samples (i.e., 0.32-0.33\%). However, another strictly anaerobic bacterium, Desulfitobacterium, which is capable of using a wide variety of electron acceptors, such as nitrate, sulfite, metals, humic acids, and halogenated organic compounds, can use $\mathrm{H}_{2}$ as an electron donor to facilitate sulfate reduction and methanogenesis (Villemur et al., 2006) was twice as abundant in the IC4 $(0.2 \%)$ than in the IC8 sample
(0.1\%). Sulfate-reducing Thermodesulfovibrio species from the Nitrospirae division were found at 0.09 and $0.06 \%$ in the IC4 and IC8 samples, respectively.

\subsection{Similarities and dissimilarities in the microbial communities based on functional annotation}

In contrast to the taxonomical assignment, the functional annotation of the metagenomes exhibited a similar structure for the microbial communities. Essential portions of sequencing data ranging from $51.9 \%$ in IC4 to $49.1 \%$ in IC8 were assigned to unknown proteins, while $37.6 \%$ (IC4) and $44.1 \%$ (IC8) were annotated proteins. A comparison of the metagenomes at the function level using the SEED - the database for bioinformatic research (Overbeek et al., 2005) - genome annotations and profile scatter plots showed that the IC4 and IC8 metagenomes possess $>83 \%$ similarity at the function level (Supplement Fig. S1). Functional analysis of the IC4 and IC8 metagenomes demonstrated that, among the annotated protein sequences, the most abundant groups represented housekeeping functions, including carbohydrate metabolism (16.6 and $17.7 \%$ ), amino acid biosynthesis (13.8 and $14.8 \%$ ), and vitamin and protein metabolism (12.1 and $13.2 \%$ ). Approximately 4.1 and $3.7 \%$ of annotated reads were related to stress response, including a high proportion of oxidative-stress- (52 and 48\%) and osmoticstress- (13 and $12 \%$ ) related sequences (Fig. 3 ). The functional potential documented through the metagenome provides the information on how many different genes may exist in a sample, but it does not give any indication of whether these genes are expressed in permafrost. If slow metabolic activity at subfreezing temperatures in permafrost exists as shown in the laboratory studies (Rivkina et al., 2000) then such a community may develop adaptations directed by sediments' physicochemical properties. Correlations between methane concentrations and both methanogenic community structure and functional profile derived from metagenomics shown in the current study suggest that the genomic data could be used as biomarkers for methanogenesis; however, additional approaches are needed to provide evidence for metabolic activity in situ. One such method is a phospholipid analysis. Phospholipid fatty acids (PLFAs) and phospholipid ether lipids (PLELs) are suitable biomarkers for estimation of either viable Bacteria and Eukarya or living Archaea, respectively. For example, Bischoff et al. (2013) correlated PLEL amounts with methane concentrations in Holocene sediments, suggesting living archaea in those permafrost samples. Though their study did not find any correlation between PLFA/PLEL markers and methane concentration in the late Pleistocene sediments, the possible presence of the inactive methanogenic community or storage of methane previously produced and trapped within the sediments cannot be ruled out. 


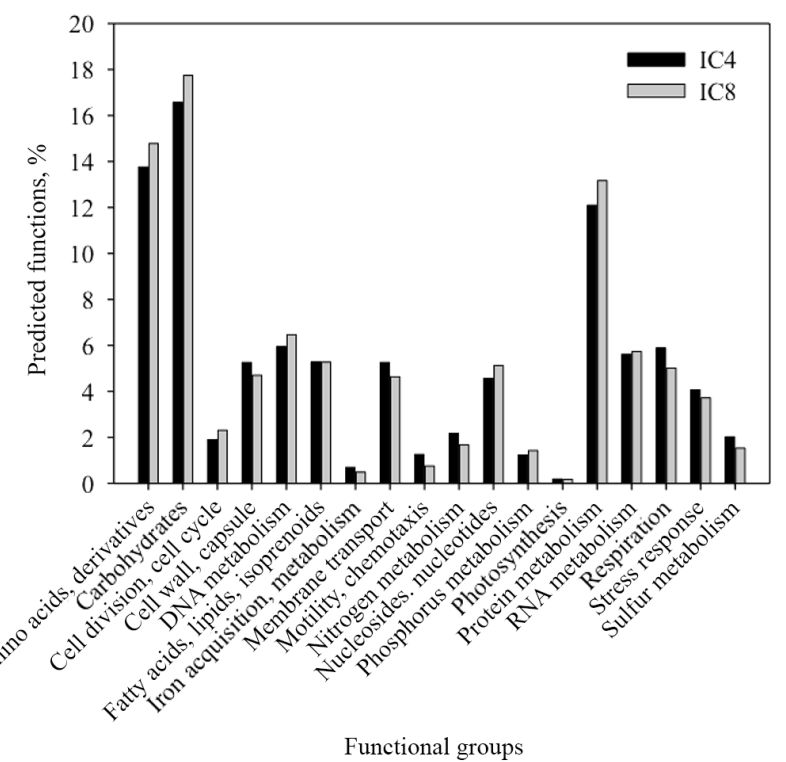

Figure 3. Percentage of gene sequences associated with different functions in the annotated protein sequences within IC4 and IC8 metagenomes.

\subsubsection{Methane metabolism}

Analyses using the KEGG (Kyoto Encyclopedia of Genes and Genomes) database (Kanehisa and Goto, 2000) (Table 2) demonstrated that several functional genes directly related to methanogenesis are abundant in the IC4 metagenome (Fig. 4), including genes coding for F420dependent methylene-H4 MPT reductase (Enzyme Commission number, EC 1.5.99.11), formylmethanofuran dehydrogenases $(f m d)$ (EC 1.2.99.5), CoB-CoM heterodisulfide reductases (EC 1.8.98.1), F420-reducing hydrogenases (EC 1.12.98.1), and methylenetetrahydromethanopterin dehydrogenases (mer) (EC 1.5.99.9). All of these genes, with the exception of F420-dependent methylene-H4 MPT reductase, were also present in the IC8 metagenome, though in lower amounts. For example, the gene coding for the enzyme catalyzing the last step of methanogenesis, methyl-coenzyme $\mathrm{M}$ reductase (MCR) (EC 2.8.4.1), was represented by 1333 hits in IC4 but only by nine hits in the IC 8 metagenome (Table 2).

\subsubsection{Nitrogen metabolism}

The abundance of genes associated with nitrogen metabolism was higher in the IC4 metagenome than in that of IC8 ( $2.2 \%$ vs. $1.7 \%)$. The percentage of genes related to nitrogen metabolism detected in permafrost was slightly higher than the relative abundance $(1.3 \%)$ of genes responsible for nitrogen metabolism reported in metagenomes examined from glacier ice of the Northern Schneeferner (Simon et al., 2009). Notably, in the IC8 metagenome the gene nifH coding for

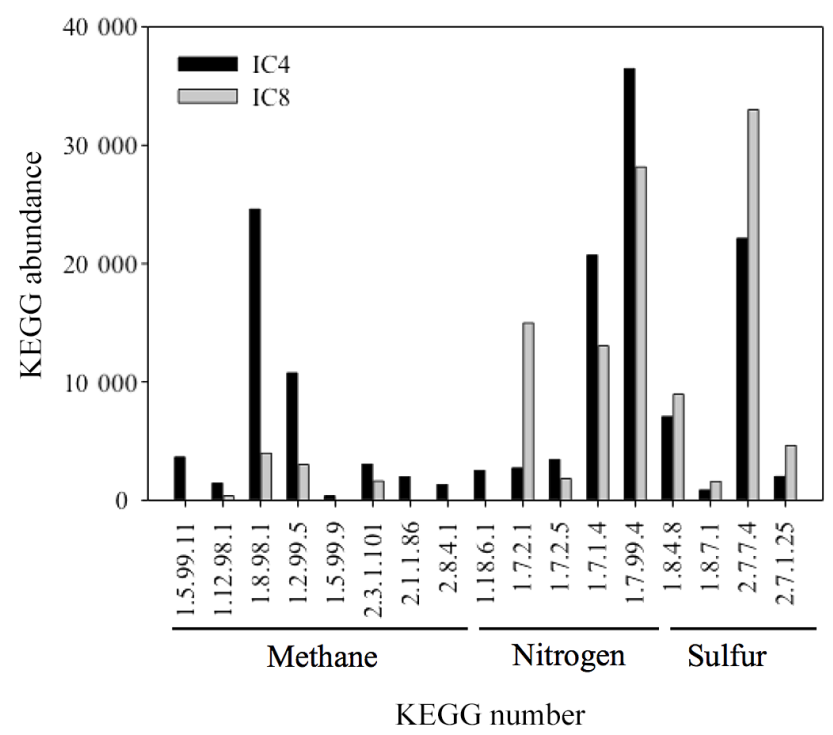

Figure 4. KEGG abundance of the selected functional gene sequences found within IC4 and IC8 metagenomes. Genes found in low abundance were not included in the figure. Genes from methane, nitrogen, and sulfur metabolic pathways are underlined. The enzyme name that corresponds to each KEGG number is given in Table 2.

a nitrogenase (EC 1.18.6.1), which performs nitrogen fixation, was represented by only seven sequences. These genes were mainly associated with Proteobacteria $(43.7 \%)$ represented by Bradyrhizobium sp., Azoarcus sp., Mesorhizobium loti, and Actinobacteria (Frankia sp., 41\%). In the IC4 metagenome, 90 features corresponding to nifH gene were detected, and these nitrogenase sequences were predominantly linked with Proteobacteria $(33.5 \%)$. Nitrogenase genes related to Firmicutes (primarily Desulfitobacterium hafniense and "Alkaliphilus metalliredigens") and Actinobacteria (Frankia species) constituted 17.6 and 15\%, respectively. Interestingly, nifH genes of cyanobacterial origin (primarily linked to Nostoc species) were detected exclusively within the IC4 metagenome (12.9\%).

Genes connected with the denitrification processes (Table 2), such as nitrate reductase (EC 1.7.99.4) and nitrite reductase (EC 1.7.2.1), were found in both metagenomes (Fig. 4). The nitrate reductase ( $\operatorname{ar} G, \mathrm{EC} 1.7 .99 .4$ ) sequences predominating within the IC4 metagenome came from more diverse phylogenetic groups in contrast to $\operatorname{nar} G$ gene from IC8. By contrast, even though nitrite reductase $($ nirS $)$ genes were significantly overrepresented in IC8, their presence was detected in similar phylogenetic groups in both metagenomes (Fig. 5). The sequences related to both nitrite reductase (EC 1.7.1.4) and nitric oxide reductase (EC 1.7.2.5) were found in similar phylogenetic groups in both metagenomes with prevalence in IC4 (Fig. 5).

The ammonium oxidation pathway was represented by a few sequences related to hydroxylamine oxidase (EC 1.7.3.6) 
Table 2. Number of sequences showing homologies to genes associated with KEGG pathways within the IC4 and IC8 metagenomes. Data were generated by searching in hierarchical classification table based upon SubSystems annotation source.

\begin{tabular}{|c|c|c|c|}
\hline Enzyme nomenclature & Function and enzyme profile & IC4 & IC8 \\
\hline \multicolumn{4}{|c|}{ Methane metabolism } \\
\hline EC 1.5.99.11 & F420-dependent methylene-H4 MPT reductase & 3649 & 0 \\
\hline EC 1.12.98.1 & Coenzyme F420 hydrogenase & 1441 & 370 \\
\hline EC 1.8.98.1 & CoB-CoM heterodisulfide reductase & 24601 & 3982 \\
\hline EC 1.2.99.5 & Formylmethanofuran dehydrogenase & 10757 & 3012 \\
\hline EC 1.5.99.9 & Methylenetetrahydromethanopterin dehydrogenases & 370 & 3 \\
\hline EC 2.8.4.1 & Methyl-coenzyme $\mathrm{M}$ reductase & 1333 & 9 \\
\hline EC 2.3.1.101 & Formylmethanofuran-tetrahydromethanopterin $\mathrm{N}$-formyltransferase & 3056 & 1642 \\
\hline EC 2.1.1.86 & Tetrahydromethanopterin S-methyltransferase & 1997 & 9 \\
\hline \multicolumn{4}{|c|}{ Nitrogen metabolism } \\
\hline EC 1.18.6.1 & Nitrogenase (molybdenum-iron) alpha chain nifH & 2519 & 42 \\
\hline EC 1.7.2.1 & Copper-containing nitrite reductase & 1824 & 11405 \\
\hline EC 1.7.2.5* & Nitric oxide reductase & 3440 & 1838 \\
\hline EC 1.7.1.4 & Nitrite reductase $[\mathrm{NAD}(\mathrm{P}) \mathrm{H}]$ small subunit & 20713 & 13041 \\
\hline EC 1.7.99.4 & Respiratory nitrate reductase alpha chain $\operatorname{narG}$ & 36476 & 28169 \\
\hline $\mathrm{EC}$ & Ammonia monooxygenase & 509 & 324 \\
\hline EC 1.7.3.4 & Hydroxylamine oxidase & 517 & 103 \\
\hline EC 1.7.99.6 & Nitrous oxide reductase & 61 & 46 \\
\hline \multicolumn{4}{|c|}{ Sulfur metabolism } \\
\hline EC 1.8.4.8 & Phosphoadenylyl-sulfate reductase [thioredoxin] & 7521 & 11165 \\
\hline EC 1.8.7.1 & Ferredoxin-sulfite reductase & 2587 & 8920 \\
\hline EC 2.7.7.4 & Sulfate adenylyltransferase subunit 2 & 15449 & 23435 \\
\hline EC 2.7.1.25 & Adenylylsulfate kinase & 22898 & 22418 \\
\hline EC 1.8.3.1 & Sulfite oxidase & 14353 & 13968 \\
\hline \multicolumn{4}{|c|}{ Stress response } \\
\hline EC 1.11.1.6 & Catalase & 74622 & 41693 \\
\hline EC 1.15.1.1 & Manganese superoxide dismutase & 8922 & 13302 \\
\hline EC 1.11.1.7 & Peroxidase & 35552 & 19698 \\
\hline EC 1.15.1.1 & Superoxide dismutase $[\mathrm{Cu}-\mathrm{Zn}]$ precursor & 2855 & 1327 \\
\hline EC 1.15.1.1 & Superoxide dismutase $[\mathrm{Fe}]$ & 7221 & 3109 \\
\hline EC 1.1.99.1 & Choline dehydrogenase & 25244 & 18018 \\
\hline EC 1.2.1.8 & Betaine-aldehyde dehydrogenase & 10022 & 12782 \\
\hline NR & Chaperone protein DnaK & 78365 & 89944 \\
\hline NR & Interacting protein DnaJ & 32897 & 45343 \\
\hline
\end{tabular}

* The current KEGG number has been created for enzyme EC 1.7.99.7.

genes in known nitrifying bacteria such as Nitrosomonas eutropha, Nitrosococcus oceani, Nitrosospira multiformis, and some others. Gene coding for ammonia monooxygenase (EC 1.14.99.39) were not detected in either metagenome by a search with its EC number. However, a search for ammonia monooxygenase using functional hierarchies such as KEGG orthologs yielded 10 hits in IC4 and 4 hits in IC8, while SubSystems showed presence of 509 hits in IC4 and 324 hits in IC8. The ammonia monooxygenase sequences were annotated as methane monooxygenase (EC 1.14.13.25). It should be noted that the particulate methane monooxygenase and ammonia monooxygenase are related and occur in both methanotrophs and ammonia oxidizers (Holmes et al., 1995). These enzymes have wide substrate specificity catalyzing the oxidation of various substrates including ammonia, methane, halogenated hydrocarbons, and aromatic molecules (Arp et al., 2002). Overall, the low abundance of ammonia oxidizers presumably represents the rare utilization of this pathway by permafrost bacteria in studied environments. Similar results were also reported for metagenomes from other cold environments, e.g., high-Arctic hypersaline subzero spring (Lay et al., 2013) and Arctic snow packs (Larose et al., 2013). 


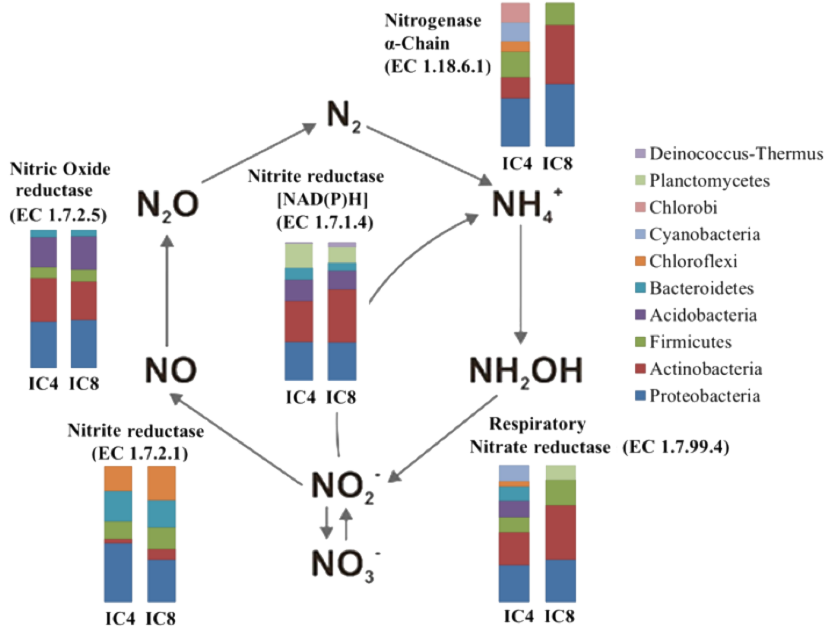

Figure 5. Phylogenetic distribution of the sequences related to nitrogen metabolism within the IC4 and IC8 metagenomes.

\subsubsection{Sulfur metabolism}

Sequences associated with sulfur metabolism were present in both IC4 and IC8 metagenomes and related to both reduction and oxidation (Table 2 and Fig. 6). Overall, genes coding for sulfate reduction were more abundant in the IC8 metagenome, including genes for sulfate adenylyltransferase (EC 2.7.7.4), phosphoadenylyl-sulfate reductase (EC 1.8.4.8), and ferredoxin-sulfite reductase (EC 1.8.7.1). Higher abundance of enzymes associated with sulfate reduction (Fig. 4) and higher concentrations of $\mathrm{SO}_{4}^{2-}$ (Table 1), as well as an absence of methane in the IC8 sample, may suggest that sulfate reduction probably dominated methanogenesis or took part in the anaerobic oxidation of methane at the time the sediments were formed. Taxonomic distribution of associated species was similar in both metagenomes, with the exception of sulfate adenylyltransferase, which was represented in IC4 by sequences related mainly to Proteobacteria and Actinobacteria. In the IC8 sample this gene was of more diverse phylogenetic origin (Fig. 6). A few sulfur oxidation genes detected were associated with Renibacterium salmoninarum and Gordonia bronchialis in IC8 and Mycobacterium species and Sinorhizobium meliloti in IC4.

\subsubsection{Stress response}

Genes associated with stress response were detected in both of the metagenomes (33683 hits in IC4 metagenome and 28557 in IC8) (Table 2). The three most abundant groups present corresponded to oxidative stress, heat shock, and osmotic stress response genes. Sequences related to oxidative stress originated principally from Proteobacteria, Actinobacteria, and Firmicutes (5148 features in IC4 and 3832 features in IC8) and included genes for catalase (EC 1.11.1.6), peroxidase (EC 1.11.1.7), and different superoxide dismu-

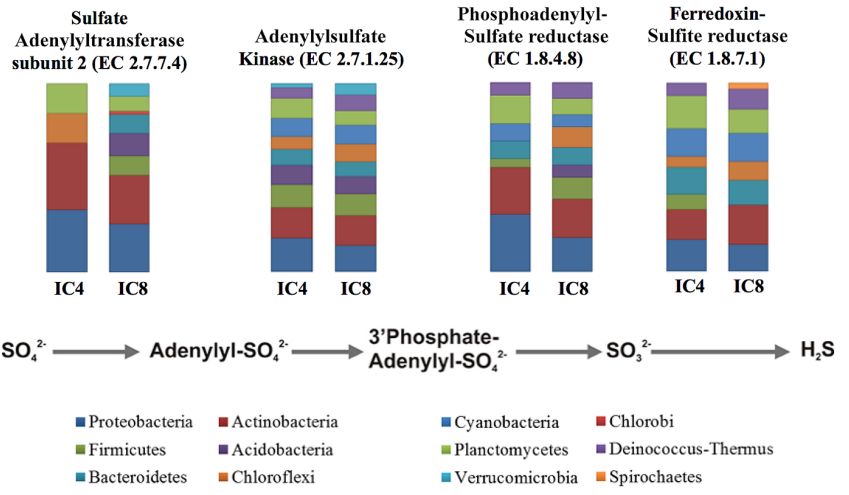

Figure 6. Phylogenetic distribution of the sequences related to sulfur metabolism (sulfur reduction) within the IC4 and IC8 metagenomes.

tases (EC 1.15.1.1). Their occurrence is presumably explained by increased oxygen solubility at low temperatures and associated increase in reactive oxygen species concentration (Chattopadhyay, 2006). Sequences related to osmotic stress were represented by the genes involved in the synthesis and uptake of compatible solutes including choline, betaine, periplasmic glucan, and ectoine. Genes for osmoprotectant ABC transporters were also detected. Choline dehydrogenase (EC 1.1.99.1) (222 features in IC4 and 213 features in IC8 mainly from Proteobacteria and Actinobacteria) and betaine-aldehyde dehydrogenase (EC 1.2.1.8) (166 features in IC4 and 186 features in IC8 from Proteobacteria, Actinobacteria, and Firmicutes) were the most abundant enzymes of this class. This emphasizes the importance of betaine osmolyte for the osmoprotection of members in microbial communities from subfreezing environments. The genes that encoded the heat shock proteins were mainly represented by the chaperone protein DnaK (816 hits in IC4 and 54 in IC8) and its interacting protein DnaJ (759 hits in IC4 and 67 in IC8). These proteins are among the most plentiful chaperons in the bacterial cell and often prevalent in microorganisms from cold environments (D’Amico et al., 2006).

\subsection{Implication of metagenomic sequencing data for the analysis of the samples origin and evolution}

The application of biological markers for paleoreconstructions in various environmental sites has been used occasionally: for example, utilization of lipid analyses for petroleum reservoir formation and maturation (Seifert and Moldowan, 1981), analysis of fossil chironomid assemblages in the Holocene lake-sediment cores (south-central Alaska) for evaluating anthropogenic climatic changes and quantitative paleo-temperature reconstructions (Clegg et al., 2010), and analyses of fossil ostracodal assemblages from the Arctic seas for reconstruction of coastline and interpretation of environmental differences in Arctic areas (Stepanova et al., 2010). To track the occurrence and dis- 
tribution of microorganisms in the environment, the gDNA and DNA fragments amplified with PCR can be employed as biological markers. Therefore, we anticipated that integration of the next-generation sequencing capabilities with phospholipid analysis and approaches in microbial ecology (such as linking microbial community composition and environmental processes involved in carbon, nitrogen, and sulfur cycling) could be used for paleo-reconstructions.

The late Pleistocene Ice Complex or Yedoma deposits are widely distributed across northeastern Siberia and their distribution relates to a number of geomorphological settings, for example (1) low-elevation coastal mountains as the main sediment sources for Yedoma, (2) Yedoma areas comprising separate bedrock elevations (100-400 m high), and (3) extended lowland areas dominated by large and numerous thermokarst basins and lakes with Yedoma hills present between them (Schirrmeister et al., 2013). The question of which processes formed these deposits has been a matter of debate in the last several decades. Several hypotheses have been proposed about the origin of the late Pleistocene Ice Complex, including eolian (Tomirdiaro et al., 1984; Tomirdiaro and Chernen'k'ii, 1987), alluvial (Rozenbaum, 1981), and polygenetic (Konishchev and Kolesnikov, 1981; Sher et al., 1987) formation. Different opinions on the origin of these deposits have been summarized in the recent publications of Schirrmeister et al. (2011, 2013). It was suggested that the ice-rich syngenetic permafrost of the late Pleistocene Ice Complex developed in a cold-arid climate under less hydromorphic conditions than the lake and lake-alluvial sediments (Schirrmeister et al., 2013; Rivkina et al., 2006). Cold-arid climate was presumably an important factor for Yedoma formation and Bischoff et al. (2013) found that Yedoma formed on Kurungnakh Island during cold and dry period from $\sim 32000$ to 16000 years ago had a less abundant community of methanogenic archaea and low amounts of methane trapped within the sediments. The Yedoma sediments located on the Yana-Indigirka, and Kolyma lowlands have been characterized by the absence of methane (Rivkina et al., 2007; Rivkina and Kraev 2008) and much lower redox potential and iron $\left(\mathrm{Fe}^{2+}\right)$ content in comparison to permafrost layers of lake and lake-alluvial origin in the same area (Rivkina et al., 2006).

A comparison of the two late Pleistocene permafrost metagenomes from samples of different genesis, i.e., of lake origin from the floodplain and from Yedoma, revealed differences in the composition of the microbial community that reflect the conditions under which these deposits were formed. These data uncovered significant distinctions in microbial community compositions between Yedoma and lake-alluvial sediments. The relatively low abundance of methanogenic archaea, the limited presence of enzymes from the carbon and nitrogen cycles, the higher abundance of enzymes from the sulfate reduction process, and the presence of methanotrophic bacteria could explain the absence of methane in Yedoma deposits and provide evidence that the formation of these sediments took place under much more aerobic conditions. In other words, we may assume that during the late Pleistocene period, nearly 30000 years ago, different environmental conditions predetermined biogeochemical regimes and composition of microbial communities of the studied samples. Similar to our study, a recent survey of soil taxonomic, phylogenetic, and functional diversity has demonstrated that metagenomic approaches can be used to build a predictive understanding of variations in microbial diversity and functions across terrestrial biomes (Fierer et al., 2012).

\subsection{Potential limitation of analysis}

Shotgun metagenomic sequencing provides insight into the identity and functional diversity of microbial communities. Although this approach is a powerful tool for understanding microbial structure and function, there are a number of potential limitations that may bias conclusions. The limitations and biases, which may be introduced throughout sampling and processing of environmental samples, have been reviewed recently (Hazen et al., 2013). Keeping in mind that obtaining a representative sample is the most fundamental step in monitoring microbial communities, we selected samples based on their similar age, close total carbon content, and significant differences in methane concentrations. We expected that minimal biases were introduced during coring, transportation, and storage, because the permafrost samples were collected following the same technique (Shi et al., 1997) and were transported frozen and stored at $-20^{\circ} \mathrm{C}$ in the Laboratory of Soil Cryology, Pushchino. To obtain average gDNA probes and generate enough gDNA for downstream applications, we used eight replicates from each permafrost sample and the PowerSoil ${ }^{\circledR}$ DNA Extraction Kit (MO BIO Laboratories Inc., USA), which showed high gDNA extraction efficiency (Vishnivetskaya et al., 2014). To ensure gDNA integrity, the gDNA solutions were properly stored at $-20^{\circ} \mathrm{C}$ in the laboratory and shipped on dry ice to the CRG Genomics Core Facility (Centre for Genomic Regulation, Barcelona, Spain) for sequencing. To decrease biases during metagenome sequencing we did not utilize multiple displacement amplification (MDA) to amplify the total community gDNA from low biomass permafrost samples; rather, we used multiple replicates to obtain enough gDNA for downstream applications. Keeping in mind that interpretation of metagenomic data is highly dependent upon the depth of sequencing, accurate annotation, and comprehension of database (Hazen et al., 2013), bioinformatic analyses were performed in the same fashion for both samples that allowed accurate comparison of these metagenomes. 


\section{Conclusions}

In the current study, we performed a comparative analysis of the two permafrost samples isolated from lake sediments and ice complex with utilization of the metagenomic sequencing approach. We have shown that the presence of methane in one sample and its absence in the second are associated with the prevalence of the certain groups of microorganisms and their corresponding genes. The possible scenario of the development of both sampled Yedoma and lake sediments can be proposed on the basis of these findings. Analysis of metagenome from IC4, a sample of the lake sediments, demonstrated occurrence of many physicochemical reactions such as denitrification, iron reduction, and sulfate reduction, which could reduce environmental redox potential and ultimately create favorable conditions for development of methanogenic community and methanogenesis. Metagenome composition of IC8 shows that physicochemical condition in the sediments did not favor the methanogenic activity, hence the absence of biogenic methane in the late Pleistocene Ice Complex on the Kolyma-Indigirka lowland.

The obtained results demonstrate that the metagenomic analysis of permafrost may give additional information on the environmental conditions during permafrost sediment formation.

\section{The Supplement related to this article is available online at doi:10.5194/bg-13-2207-2016-supplement.}

Author contributions. Elizaveta Rivkina, Lada Petrovskaya, and Fyodor Kondrashov designed the research; Lyubov Shmakova, Maria Tutukina, Lada Petrovskaya, and Elizaveta Rivkina performed research; Lyubov Shmakova and Maria Tutukina extracted DNA; Fyodor Kondrashov performed DNA sequencing; Elizaveta Rivkina, Lada Petrovskaya, Kirill Krivushin, Tatiana Vishnivetskaya, and Arthur Meyers analyzed data; Elizaveta Rivkina and Fyodor Kondrashov contributed new reagents and analytical tools; Elizaveta Rivkina, Lada Petrovskaya, and Tatiana Vishnivetskaya wrote the paper.

Acknowledgements. This work was supported by grants from the Russian Scientific Fund (14-14-01115) to Elizaveta Rivkina; from the National Science Foundation (DEB-1442262) to Tatiana Vishnivetskaya; and from the HHMI International Early Career Scientist Program (55007424), the EMBO Young Investigator Programme, MINECO (BFU2012-31329 and Sev-2012-0208), and the AGAUR program (2014 SGR 0974) to Fyodor Kondrashov. Support from the Russian Scientific Fund (14-14-01115) was allocated for sample collection, gDNA isolation, and analysis of metagenomic data.

Edited by: V. Brovkin

\section{References}

Angly, F. E., Willner, D., Prieto-Davó, A., Edwards, R. A., Schmieder, R., Vega-Thurber, R., Antonopoulos, D. A., Barott, K., Cottrell, M. T., Desnues, C., Dinsdale, E. A., Furlan, M., Haynes, M., Henn, M. R., Hu, Y., Kirchman, D. L., McDole, T., McPherson, J. D., Meyer, F., Miller, R. M., Mundt, E., Naviaux, R. K., Rodriguez-Mueller, B., Stevens, R., Wegley, L., Zhang, L., Zhu, B., and Rohwer, F.: The GAAS metagenomic tool and its estimations of viraland microbial average genome size in four major biomes, PLoS Comput. Biol., 5, e1000593, doi:10.1371/journal.pcbi.1000593, 2009.

Anthony Walter, K. M., Zimov, S. A., Grosse, G., Jones, M. C., Anthony, P. M., Chapin III, F. S., Finlay, J. C., Mack, M. C., Davydov, S., Frenzel, P., and Frolking, S.: A shift of thermokarst lakes from carbon sources to sinks during the Holocene epoch, Nature, 511, 452-456, 2014.

Arp, D. J., Sayavedra-Soto, L. A., and Hommes, N. G.: Molecular biology and biochemistry of ammonia oxidation by Nitrosomonas europaea, Arch. Microbiol., 178, 250-255, 2002.

Bailly, J., Fraissinet-Tachet, L., Verner, M.-C., Debaud, J.-C., Lemaire, M., Wésolowski-Louvel, M., and Marmeisse, R.: Soil eukaryotic functional diversity, a metatranscriptomic approach, The ISME Journal, 1, 632-642, 2007.

Bischoff, J., Mangelsdorf, K., Gattinger, A., Schloter, M., Kurchatova, A.N., Herzschuh, U., and Wagner, D.: Response of methanogenic archaea to Late Pleistocene and Holocene climate changes in the Siberian Arctic, Global Biogeochem. Cy., 27, 305-317, 2013.

Brouchkov, A. and Fukuda, M.: Preliminary Measurements on Methane Content in Permafrost, Central Yakutia, and some Experimental Data 21, Permafrost. Periglac., 13, 187-197, 2002.

Chattopadhyay, M. K.: Mechanism of bacterial adaptation to low temperature, J. Biosciences, 31, 157-165, 2006.

Clegg, B. F., Clarke, G. H., Chipman, M. L., Chou, M., Walker, I. R., Tinner, W., and Hu, F. S.: Six millennia of summer temperature variation based on midge analysis of lake sediments from Alaska, Quaternary Sci. Rev., 29, 3308-3316, 2010.

D’Amico, S., Collins, T., Marx, J. C., Feller, G., and Gerday, C.: Psychrophilic microorganisms: challenges for life, EMBO Rep, 7, 385-389, 2006

Ellenbroek, F. M. and Cappenberg, T. E.: DNA-synthesis and tritiated-thymidine incorporation by heterotrophic fresh-water bacteria in continuous culture, Appl. Environ. Microb., 57, 16751682, 1991.

Fierer, N., Leff, J. W., Adams, B. J., Nielsen, U. N., Bates, S. T., Lauber, C. L., Owens, S., Gilbert, J. A., and Caporaso, J. G.: Cross-biome metagenomic analyses of soil microbial communities and their functional attributes, P. Natl. Acad. Sci. USA, 109, 21390-21395, 2012.

Gilichinsky, D. and Rivkina, E.: Permafrost microbiology, in: Encyclopedia of Geobiology, edited by: Reitner, J. and Thiel, V., Springer, Dordrecht, the Netherlands, 726-732, 2011.

Glockner, F. O., Kube, M., Bauer, M., Teeling, H., Lombardot, T., and Ludwig, W., Gade, D., Beck, A., Borzym, K., Heitmann, K., Rabus, R., Schlesner, H., Amann, R., and Reinhardt,R.: Complete genome sequence of the marine planctomycete Pirellula sp. strain 1, P. Natl. Acad. Sci. USA, 100, 8298-8303, 2003.

Graham, D. E., Wallenstein, M. D., Vishnivetskaya, T. A., Waldrop, M. P., Phelps, T. J., Pfiffner, S. M., Onstott, T. C., Whyte, L. G., 
Rivkina, E. M., Gilichinsky, D. A., Elias, D. A., Mackelprang, R., VerBerkmoes, N. C., Hettich, R. L., Wagner, D., Wullschleger, S. D., and Jansson, J. K.: Microbes in thawing permafrost: the unknown variable in the climate change equation, ISME J., 6, 709-712, 2012.

Harmsen, H. J. M., Van Kuijk, B. L. M., Plugge, C. M., Akkermans, A. D. L., De Vos, W. M., and Stams, A. J. M.: Syntrophobacter fumaroxidans sp. nov., a syntrophic propionate-degrading sulfate-reducing bacterium, Int. J. Syst. Bacteriol., 48, 13831387, 1998.

Hazen, T. C., Rocha, A. M., and Techtmann, S. M.: Advances in monitoring environmental microbes, Curr. Opin. Biotech., 24, 526-533, 2013.

Holmes, A. J., Costello, A., Lidstrom, M. E., and Murrell, J. C.: Evidence that particulatemethane monooxygenase and ammonia monooxygenase may be evolutionarily related, FEMS Microbiol. Lett., 132, 203-208, 1995.

Jackson, B. E., Bhupathiraju, V. K., Tanner, R. S., Woese, C. R., and McInerney, M. J.: Syntrophus aciditrophicus sp. nov., a new anaerobic bacterium that degrades fatty acids and benzoate in syntrophic association with hydrogen-using microorganisms, Arch. Microbiol., 171, 107-114, 1999.

Jansson, J. K. and Tas, N.: The microbial ecology of permafrost, Nature Rev. Microbiol., 12, 414-425, 2014.

Kanehisa, M. and Goto, S.: KEGG: Kyoto Encyclopedia of Genes and Genomes, Nucleic Acids Res., 28, 27-30, 2000.

Khmelenina, V. N., Makutina, V. A., Kalyuzhnaya, M. G., Rivkina, E. M., Gilichinsky, D. A., and Trotsenko, Y.: Discovery of viable methanotrophic bacteria in permafrost sediments of northeast Siberia, Dokl. Biol. Sci., 384, 235-237, 2002.

Konishchev, V. N. and Kolesnikov, S. F.: Specialities of structure and composition of late Cenozoic deposits in the section of Oyogossky Yar, in: Problems of Cryolithology, MGU Publishing, Moscow, 107-117, 1981 (in Russian).

Kraev, G. N., Schultze, E. D., and Rivkina, E. M.: Cryogenesis as a factor of methane distribution in layers of permafrost, Dokl. Earth Sci., 451, 882-885, 2013.

Krivushin, K. V., Shcherbakova, V. A., Petrovskaya, L. E., and Rivkina, E. M.: Methanobacterium veterum sp nov., from ancient Siberian permafrost, Int. J. Syst. Evol. Micr., 60, 455-459, 2010.

Krivushin, K., Kondrashov, F., Shmakova, L., Tutukina, M., Petrovskaya, L., and Rivkina, E.: Two metagenomes from Late Pleistocene northeast Siberian permafrost, Genome Announ., 3, e01380-14, doi:10.1128/genomeA.01380-14, 2015.

Larose, C., Dommergue, A., and Vogel, J. G.: Microbial nitrogen cycling in Arctic snowpacks, Environ. Res. Lett., 8, 035004, doi:10.1088/1748 9326/8/3/035004, 2013.

Lau, M. C. Y., Stackhouse, B. T., Layton, A. C., Chauhan, A., Vishnivetskaya, T. A., Chourey, K., Ronholm, J., Mykytczuk, N. C. S., Bennett, P. C., Lamarche-Gagnon, G., Burton, N., Pollard, W. H., Omelon, C. R., Medvigy, D. M., Hettich, R. L., Pfi ner, S. M., Whyte, L. G., and Onstott, T. C.: An active atmospheric methane sink in high Arctic mineral cryosols, ISME J., 9, 18801891, 2015.

Lay, C. Y., Mykytczuk, N. C., Yergeau, E., Lamarche-Gagnon, G., Greer, C. W., and Whyte, L. G.: Defining the functional potential and active community members of a sediment microbial community in a high-arctic hypersaline subzero spring, Appl. Environ. Microb., 79, 3637-3648, 2013.
Legendre, M., Bartoli, J., Shmakova, L., Jeudy, S., Labadie, K., Adrait, A., Lescot, M., Poirot, O., Bertaux, L., Bruley, C., Couté, Y., Rivkina, E., Abergel, C., and Claverie, J.-M.: Thirty thousand-year-old distant relative of giant icosahedral DNA viruses with a pandoravirus morphology, P. Natl. Acad. Sci. USA, 111, 4274-4279, 2014.

Liebner, S. and Wagner, D.: Abundance, distribution and potential activity of methane oxidizing bacteria in permafrost soils from the Lena Delta, Siberia, Environ. Microbiol., 9, 107-117, 2007.

Mackelprang, R., Waldrop, M. P., DeAngelis, K. M., David, M. M., Chavarria, K. L., Blazewicz,S. J., Rubin, E. M., and Jansson, J. K.: Metagenomic analysis of a permafrost microbialcommunity reveals a rapid response to thaw, Nature, 480, 368-371, 2011.

Meyer, F., Paarmann, D., D’Souza, M., Olson, R., Glass, E., Kubal, M., Paczian, T., Rodriguez, A., Stevens, R., Wilke, A., Wilkening, J., and Edwards, R. A.: The metagenomics RAST server - a public resource for the automatic phylogenetic and functional analysis of metagenomes, BMC Bioinformatics, 9, 386, doi:10.1186/1471-2105-9-386, 2008.

Morozova, D. and Wagner D.: Stress response of methanogenic archaea from Siberian permafrost compared with methanogens from nonpermafrost habitats, FEMS Microbiol. Ecol., 61 , 16$25,2007$.

Newcombe, R. G.: Two-sided confidence intervals for the single proportion: comparison of seven methods, Stat. Med., 17, 857872, 1998.

Overbeek, R., , Begley, T., Butler, R.M., Choudhuri, J.V., Chuang, H-Yu., Cohoon, M., Valérie de Crécy-Lagard, Diaz N., Disz, T., Edwards, R., Fonstein, M., Frank, E.D., Gerdes, S., Glass,E.M., Goesmann, A., Hanson, A. Iwata-Reuy, D., Jensen, R., Jamshidi, N., Krause L., Kuba, M., Larsen, L., Linke, B., McHardy, A.C., Meyer, F., Neuweger, H., Olsen, G., Olson, R., Osterman, A., Portnoy, V., Pusch, G.D., Rodionov, D.A., Ruckert, C., Steiner, J., Stevens, R., Thiele, I., Vassieva, O., Ye, Yu., Zagnitko, O., and Vonstein, V.: The subsystems approach to genome annotation and its use in the project to annotate 1000 genomes, Nucleic Acids Res., 33, 5691-5702, 2005.

Parks, D. H. and Beiko, R. G.: Identifying biologically relevant di erences between metagenomic communities, Bioinformatics, 26, 715-721, 2010.

Raes, J., Korbel, J. O., Lercher, M. J., von Mering, C., and Bork, P.: Prediction of effective genome size in metagenomic samples, Genome Biol., 8, R10, doi:10.1186/gb-2007-8-1-r10, 2007.

Rivkina, E. and Kraev, G.: Permafrost degradation and influx of biogeogases into the atmosphere, Ninth International Conference on Permafrost, Fairbanks, USA, University of Alaska Fairbanks, 29 June-03 July, 1499-1504, 2008.

Rivkina, E., Laurinavichius, K., McGrath, J., Tiedje, J., Shcherbakova, V., and Gilichinsky, D.: Microbial life in permafrost, Adv. Space Res., 33, 1215-1221, 2004.

Rivkina, E., Kraev, G., Krivushin, K., Laurinavichius, K., Fyodorov-Davydov, D., Kholodov, A., Shcherbakova, V., and Gilichinsky, D.: Methane in permafrost of northeastern Arctic, Earth Cryosphere, 10, 23-41, 2006 (in Russian).

Rivkina, E., Shcherbakova, V., Laurinavichius, K., Petrovskaya, L., Krivushin, K., Kraev, G., Pecheritsina. S., and Gilichinsky, D.: Biogeochemistry of methane and methanogenic archaeain permafrost, FEMS Microbiol. Ecol., 61, 1-15, 2007. 
Rivkina, E. M., Friedmann, E. I., McKay, C. P., and Gilichinsky, D. A.: Metabolic activity of permafrost bacteria below the freezing point, Appl. Environ. Microbiol., 66, 3230-3233, 2000.

Rozenbaum, G. E.: Special features of lithogenesis of the alluvial planes in the Eastern Subarctic as related to the problem of the Ice (Yedoma) Complex, in: Problems of Cryolithology, MSU Press, Moscow, 87-100, 1981 (in Russian).

Schirrmeister, L., Kunitsky, V., Grosse, G., Wetterich, S., Meyer, H., Schwamborn, G., Babiy, O., Derevyagin, A., and Siegert, C.: Sedimentary characteristics and origin of the Late Pleistocene Ice Complex on North-East Siberian Arctic coastal lowlands and islands - a review, Quatern. Int., 241, 3-25, 2011.

Schirrmeister, L., Froese, D., Tumskoy, V., Grosse, G., and Wetterich, S.: Yedoma: late Pleistocene ice-rich syngenetic permafrost of Beringia, in: Encyclopedia of Quaternary Science, 2nd Edn., edited by: Elias, S., Mock, C., and Murton, J., Elsevier, Amsterdam, 542-552, 2013.

Seifert, W. K. and Moldowan, J. M.: Paleoreconstruction by biological markers, Geochim. Cosmochim. Ac., 45, 783-794, 1981.

Shcherbakova, V., Rivkina, E., Pecheritsyna, S., Laurinavichius, K., Suzina, N., and Gilichinsky, D.: Methanobacterium arcticum sp. nov., a methanogenic archaeon from Holocene Arctic permafrost, Int. J. Syst. Evol. Micr., 61, 144-147, 2011.

Sher, A., Kaplina, T., and Ovander, M.: Unified regional stratigraphic chart for the Quaternary deposits in the YanaKolyma Lowland and its mountainous surroundings, Explanatory Note, Decisions of Interdepartmental Stratigraphic Conference on the Quaternary of the Eastern USSR, Magadan, 1982, USSR Academy of Sciences, Far-Eastern Branch, NorthEasternComplex Research Institute, Magadan, USSR, 29-69, 1987 (in Russian).

Shi, T., Reeves, R. H., Gilichinsky, D. A., and Friedmann, E. I.: Characterization of viable bacteria from Siberian permafrost by 16S rDNA sequencing, Microb. Ecol., 33, 169-179, 1997.

Simon, C., Wiezer, A., Strittmatter, A. W., and Daniel, R.: Phylogenetic diversity and metabolic potential revealed in a glacier ice metagenome, Appl. Environ. Microb., 75, 7519-7526, 2009.

Stepanova, A. Y., Taldenkova, E. E., and Bauch, H. A.: Arctic quaternary ostracods and their use in paleoreconstructions, Paleontol. J., 44, 41-48, 2010.

Storey, J. D. and Tibshirani, R.: Statistical significance for genome wide studies, P. Natl. Acad. Sci. USA, 100, 9440-9445, 2003.
Storey, J. D., Taylor, J. E., and Siegmund, D.: Strong control, conservative point estimation and simultaneous conservative consistency of false discovery rates: a unified approach, J. Royal Stat. Soc. B, 66, 187-205, 2004.

Tomirdiaro, S. V. and Chernen'k'ii, B. I.: Cryogenic Deposits of East Arctic and Sub Arctic, ANSSSR Far-East-Science Center, Magadan, 1987.

Tomirdiaro, S. V., Arslanov, K. A., Chernen'kii, B. I., Tertychnaya, T. V., and Prokhorova, T. N.: New data on formation of loessice sequences in Northern Yakutia and ecological conditionsof mammoth fauna in the Arctic during the late Pleistocene, Reports Academy of Sciences USSR 278, 1446-1449, 1984 (in Russian).

Villemur, R., Lanthier, M., Beaudet, R., and Lepine, F.: The Desulfitobacterium genus, FEMS Microbiol. Rev., 30, 706-733, 2006.

Vishnivetskaya, T. A., Layton, A. C., Lau, M. C. Y., Chauhan, A., Cheng, K. R., Meyers, A. J., Murphy, J. R., Rogers, A.W., Saarunya, G. S., Williams, D. E., Pfi ner, S. M., Biggersta, J. P., Stackhouse, B. T., Phelps, T. J., Whyte, L., Sayler G. S., and Onstott, T. C.: Commercial DNA extraction kits impact observed microbial community composition in permafrost samples, FEMS Microbiol. Ecol., 87, 217-230, 2014.

Wagner, D., Schirmack, J., Ganzert L., Morozova D., and Mangelsdorf, K.: Methanosarcina soligelidi sp. nov., a desiccation- and freeze-thaw-resistant methanogenic archaeon from a Siberian permafrost-affected soil, Int. J. Syst. Evol. Microbiol., 63, 29862991, 2013.

Walter, K. M., Edwards, M. E., Grosse, G., Zimov, S. A., and Chapin, F. S.: Thermokarst lakes as a source of atmospheric $\mathrm{CH}_{4}$ during the last deglaciation, Science, 318, 633-636, 2007.

Wilke, A., Harrison, T., Wilkening, J., Field, D., Glass, E. M., Kyrpides, N., Mavrommatis, K., and Meyer, F.: The M5nr: a novel non-redundant database containing protein sequences and annotations from multiple sources and associated tools, BMC Bioinformatics, 13, 141, doi:10.1186/1471-2105-13-141, 2012.

Yergeau, E., Hogues, H., Whyte, L. G., and Greer, C. W.: The functional potential of high Arctic permafrost revealed by metagenomic sequencing, qPCR and microarray analyses, ISME J., 4, 1-9, 2010.

Zimov, S. A., Schuur, E. A. G., and Chapin, F. S.: Permafrost and the global carbon budget, Science, 312, 1612-1613, 2006. 